\title{
Article \\ A Novel Angiotensin-I-Converting Enzyme (ACE) Inhibitory Peptide from Takifugu flavidus
}

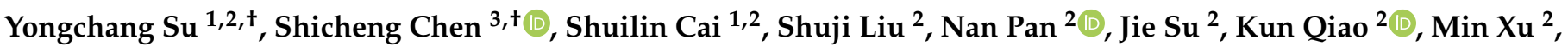 \\ Bei Chen ${ }^{2}$, Suping Yang ${ }^{1, *(1)}$ and Zhiyu Liu ${ }^{2, *}$ \\ 1 College of Chemical Engineering, Huaqiao University, Xiamen 361021, China; \\ suyongchang@stu.hqu.edu.cn (Y.S.); caishuilin@hqu.edu.cn (S.C.) \\ 2 Key Laboratory of Cultivation and High-Value Utilization of Marine Organisms in Fujian Province, Fisheries \\ Research Institute of Fujian, Xiamen 361013, China; cute506636@163.com (S.L.); npan01@qub.ac.uk (N.P.); \\ sjscut@126.com (J.S.); qiaokun@xmu.edu.cn (K.Q.); xumin1315@foxmail.com (M.X.); \\ chenbeifffri@foxmail.com (B.C.) \\ 3 Department of Clinical and Diagnostic Sciences, School of Health Sciences, Oakland University, \\ 433 Meadowbrook Road, Rochester, MI 48309, USA; schen5@oakland.edu \\ * Correspondence: yangsuping@hqu.edu.cn (S.Y.); liuzy@fafu.edu.cn (Z.L.) \\ + These authors contributed equally to this work.
}

Citation: Su, Y.; Chen, S.; Cai, S.; Liu, S.; Pan, N.; Su, J.; Qiao, K.; Xu, M.; Chen, B.; Yang, S.; et al. A Novel Angiotensin-I-Converting Enzyme (ACE) Inhibitory Peptide from Takifugu flavidus. Mar. Drugs 2021, 19 , 651. https://doi.org/10.3390/ md19120651

Academic Editor: Marialuisa Menna

Received: 21 October 2021

Accepted: 19 November 2021

Published: 23 November 2021

Publisher's Note: MDPI stays neutral with regard to jurisdictional claims in published maps and institutional affiliations.

Copyright: (c) 2021 by the authors. Licensee MDPI, Basel, Switzerland. This article is an open access article distributed under the terms and conditions of the Creative Commons Attribution (CC BY) license (https:/ / creativecommons.org/licenses/by/ $4.0 /)$.

\begin{abstract}
Alcalase, neutral protease, and pepsin were used to hydrolyze the skin of Takifugu flavidus. The T. flavidus hydrolysates (TFHs) with the maximum degree of hydrolysis (DH) and angiotensin-Iconverting enzyme (ACE)-inhibitory activity were selected and then ultra-filtered to obtain fractions with components of different molecular weights (MWs) $(<1,1-3,3-10,10-50$, and $>50 \mathrm{kDa})$. The components with MWs $<1 \mathrm{kDa}$ showed the strongest ACE-inhibitory activity with a half-maximal inhibitory concentration $\left(\mathrm{IC}_{50}\right)$ of $0.58 \mathrm{mg} / \mathrm{mL}$. Purification and identification using semi-preparative liquid chromatography, Sephadex G-15 gel chromatography, RP-HPLC, and LC-MS/MS yielded one new potential ACE-inhibitory peptide, PPLLFAAL (non-competitive suppression mode; $\mathrm{IC}_{50}$ of $28 \mu \mathrm{mmol} \cdot \mathrm{L}^{-1}$ ). Molecular docking and molecular dynamics simulations indicated that the peptides should bind well to ACE and interact with amino acid residues and the zinc ion at the ACE active site. Furthermore, a short-term assay of antihypertensive activity in spontaneously hypertensive rats (SHRs) revealed that PPLLFAAL could significantly decrease the systolic blood pressure (SBP) and diastolic blood pressure (DBP) of SHRs after intravenous administration. These results suggested that PPLLFAAL may have potential applications in functional foods or pharmaceuticals as an antihypertensive agent.
\end{abstract}

Keywords: Takifugu flavidus; hydrolysis; ACE-inhibitory activity; purification and identification; molecular docking; antihypertensive activity

\section{Introduction}

Hypertension, which is a common and serious chronic medical condition, is a major risk factor for developing cardiovascular diseases [1]. Hypertension may cause various acute diseases, such as stroke, coronary heart disease, atherosclerosis, and heart failure. It has become a serious threat to human health, impacting as much as $30 \%$ of the global adult population [2]. According to predictive statistics from the World Health Organization (WHO, Geneva, Switzerland), this chronic disease will increase in prevalence by up to $29 \%$ of the world's adult population by 2025 . The angiotensin-I-converting enzyme (ACE, EC 3.4.15.1) is a dipeptidyl carboxypeptidase that belongs to the zinc metalloenzyme family and plays a crucial role in blood pressure control via monitoring and attenuating hypertension [3]. ACE is a key enzyme in the renin-angiotensin system (RAS) and kallikrein-kinin system (KKS) since it promotes the conversion of angiotensin I to the potent vasoconstrictor angiotensin II, as well as catalyzes the degradation of the vasodilator bradykinin to raise 
blood pressure [4,5]. Therefore, the inhibition of ACE activity is a useful treatment for controlling hypertension and thus maintaining blood pressure within a normal range. Synthetic ACE inhibitors (ACEIs), such as captopril, enalapril, lisinopril, alacepril, and ramipril, are widely used in the management of hypertension [6]. Unfortunately, these drugs have a series of side effects, including hypotension, cough, taste disturbances, angioedema, skin rashes, and increased blood potassium levels [7]. Hence, numerous studies were carried out to find alternative safe ACE inhibitors from natural foods. At present, many ACE-inhibitory peptides have been screened from the enzymatic hydrolysates of food protein sources, such as milk proteins, marine organisms, meat, and plant proteins [8-12]. To date, more than 5978 types of ACE-I-inhibitory peptides have been reported in the AHTPDB (antihypertensive peptides database). Some were confirmed to exert definite hypotensive effects in spontaneously hypertensive rats (SHRs), as well as in hypertensive human volunteers [13]. Compared with ACE-inhibitory drugs, ACE-inhibitory peptides have minimal toxicity or side effects relative to synthetic ACE inhibitors [8]. Therefore, ACE-inhibitory peptides have been considered as potent alternatives to synthetic ACE inhibitors in the treatment of hypertension.

Marine organisms, which are rich in unique bioactive proteins, have been widely used in the search for ACE-inhibitory peptides. According to previous studies, many novel ACE-inhibitory peptides with efficient antihypertensive effects were obtained from marine organisms. For instance, Ghassem et al. isolated two novel ACE-inhibitory peptides, namely, LYPPP and YSMYPP, from snakehead fish sarcoplasmic protein hydrolysates, with $\mathrm{IC}_{50}$ values of 1.3 and $2.8 \mu \mathrm{mol} \cdot \mathrm{L}^{-1}$, respectively [14]. Liu et al. investigated the antihypertensive activity of a protein hydrolysate that was made from Rhopilema esculentum using compound proteinase AQ. Four novel ACE-inhibitory peptides were isolated and their $\mathrm{IC}_{50}$ values were $8.40,23.42,21.15$, and $19.11 \mu \mathrm{mol} \cdot \mathrm{L}^{-1}$ [15]. Hao Wu et al. investigated the antihypertensive effects of ACE-inhibitory peptides from shark meat hydrolysates. Four peptides with high ACE-inhibitory activity were purified; their amino acid sequences were Cys-Phe, Glu-Tyr, Met-Phe, and Phe-Glu. Cys-Phe, Glu-Tyr, and Phe-Glu were confirmed to be novel ACE-inhibitory peptides [16]. Lee et al. identified a potent ACE-inhibitory peptide from tuna frame protein (PTFP), which was composed of 21 amino acids: Gly-Asp-LeuGly-Lys-Thr-Thr-Thr-Val-Ser-Asn-Trp-Ser-Pro-Pro-Lys-Try-Lys-Asp-Thr-Pro (MW: 2482 Da, $\left.\mathrm{IC}_{50}: 11.28 \mu \mathrm{mol} \cdot \mathrm{L}^{-1}\right)$. PTFP acts as a non-competitive inhibitor against $\mathrm{ACE}$ and has an antihypertensive effect after oral administration in SHRs [17].

T. flavidus, otherwise known as tawny puffer, is mainly distributed in the inshore waters of the East China Sea, Yellow Sea, and Bohai Bay [18]. The fish is well known for its distinctive defense mechanism of inflating its body with air or water when threatened. Although its liver and ovary contain tetrodotoxin, T. flavidus is considered one of the most delicious dishes in China, Korea, and Japan for its extraordinarily palatable flavor. In addition, T. flavidus is rich in collagen, proteins, and carbohydrates, and the high content of crude proteins renders it a promising source of bioactive peptides. The current research on T. flavidus has focused primarily on artificial breeding techniques, analysis of the genome, and the nutritional composition [18-20]. However, there has been little research on the ACE-inhibitory peptides within T. flavidus.

In this study, T. flavidus was hydrolyzed using trypsin, pepsin, and alcalase. The potential ACE-inhibitory peptides of the hydrolysate solution were purified and identified using ultra-filtration, Sephadex G-15 gel chromatography, reversed-phase high-performance liquid chromatography (RP-HPLC), and liquid chromatography with tandem mass spectrometry (LC-MS/MS). Furthermore, the ACE inhibition patterns and molecular docking mechanism of the newly extracted ACE-inhibitory peptides were explored.

\section{Results and Discussion}

\subsection{Degree of Hydrolysis and ACE-Inhibitory Activity of T. flavidus Hydrolysates (TFHs)}

Proteases are necessary to release ACE-inhibitory peptides from inactive forms. Different types of proteases yield polypeptides of different compositions and sizes, which 
can affect their biological activities [21]. In this study, T. flavidus proteins were hydrolyzed in three independent reactions, with each reaction using one of three different proteases, and the ACE-inhibitory activities of different concentrations of the TFHs were assessed (Figure $1 \mathrm{~A}$ ). The half-inhibitory concentrations $\left(\mathrm{IC}_{50}\right)$ of the TFHs that were obtained with alcalase, neutral protease, and pepsin were $0.1,0.5$, and $1.6 \mathrm{mg} / \mathrm{mL}$, respectively. The alcalase-hydrolyzed product exhibited the greatest ACE-inhibitory activity, which even increased with increasing hydrolysis time (Figure 1B). These results implied a correlation between the degree of hydrolysis $(\mathrm{DH})$ and the inhibitory activity.

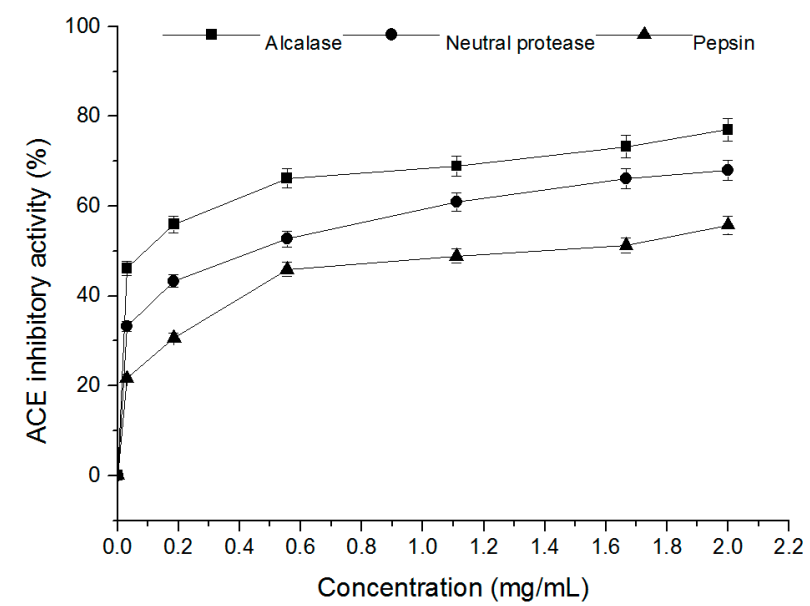

(A)

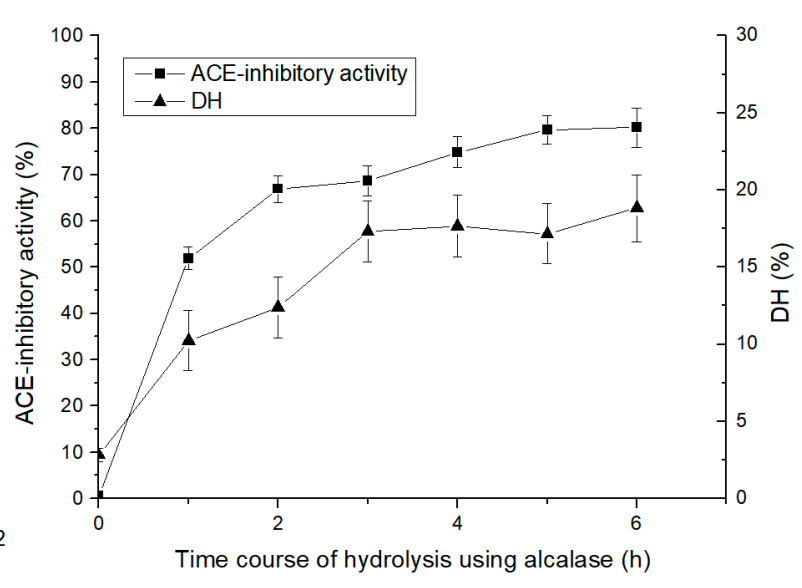

(B)

Figure 1. ACE-inhibitory activity of T. flavidus hydrolysates (TFHs). (A) The ACE-inhibitory activity of TFHs was obtained with alcalase, neutral protease, and pepsin. (B) Time course of ACE-inhibitory activity and degree of hydrolysis (DH) of TFHs that were obtained with alcalase.

Enzymatic hydrolysis is the most efficient pathway for producing bioactive peptides [22]. The biological functions of peptides are strongly affected by the used proteases, which have typical specificities and molecular masses [23]. It was reported that alcalase is an efficient enzyme for hydrolyzing fish proteins and releasing the highest number of potential bioactive (including ACE-inhibitory) peptides from the heavy chain proteins actin, collagen, and myosin [24]. In addition, alcalase tends to cleave peptide bonds that bind to aromatic (Phe, Tyr, and Trp) or uncharged branched (Ile, Val, and Leu) amino acid residues, which can significantly improve the ACE-inhibitory activity [25]. In our study, alcalase seemed to be more effective at digesting T. flavidus proteins and resulted in higher ACE-inhibitory activity compared with the other two tested proteases. Thus, alcalase was selected for the generation of ACE-inhibitory peptides from T. flavidus.

\subsection{ACE-Inhibitory Activity of the TFH and Its Ultrafiltrate Fractions}

Hydrolysis using alcalase generally yields a mixture of peptides with various sizes and sequences. Ultrafiltration is commonly used to separate the bioactive peptides with different molecular weights (MWs) from the hydrolysate [26]. We fractionated the TFHs using ultrafiltration through 1, 3, 10,30, and $50 \mathrm{kDa}$ molecular weight cut-off filtration membranes to obtain fractions with MWs $<1,1-3,3-10,10-50$, and $>50 \mathrm{kDa}$. The ACEinhibitory activity gradually increased as the MW of the components decreased (Figure 2A). The ultrafiltrate fraction with $\mathrm{MW}<1 \mathrm{kDa}$ had higher inhibitory activity, and thus lower $\mathrm{IC}_{50}(0.58 \mathrm{mg} / \mathrm{mL})$, than the fractions with $\mathrm{MW}>1 \mathrm{kDa}$ (Figure $\left.2 \mathrm{~A}, \mathrm{~B}\right)$. The results indicated that the low-MW peptides were generally more active than high-MW peptides, which was basically in accordance with the previous research $[27,28]$. It is believed that short-chain peptides can acquire a spatial conformation that allows them to be positioned within the three-dimensional conformation of the ACE, restricting the access of high-MW peptides [29]. Therefore, the $<1 \mathrm{kDa}$ fraction of TFHs was chosen for further separation and purification. 


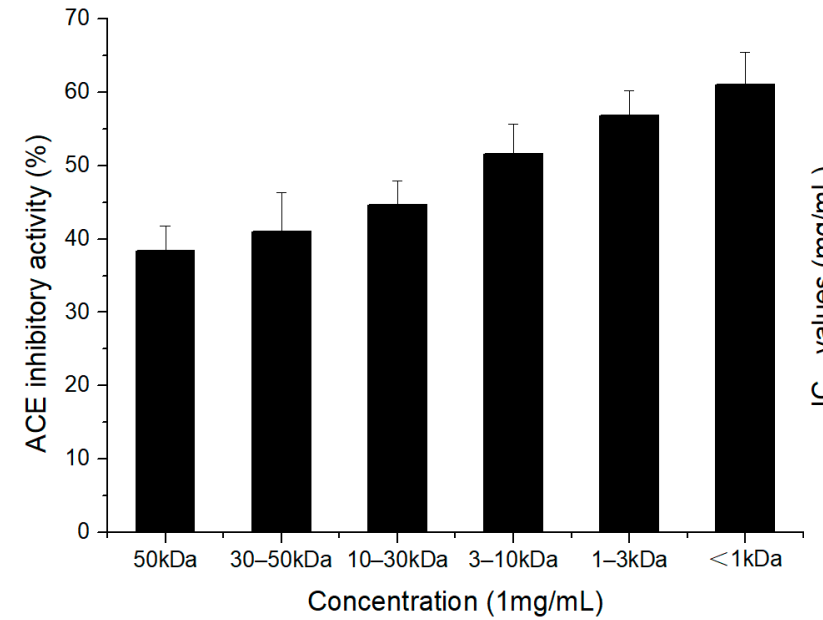

(A)

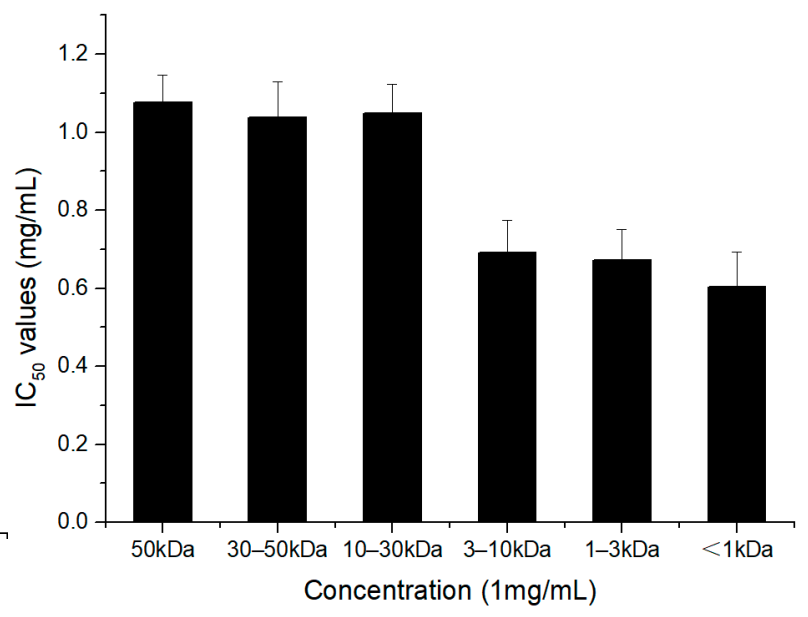

(B)

Figure 2. ACE-inhibitory activity of the TFH ultrafiltrate fractions at a concentration of $1 \mathrm{mg} / \mathrm{mL}$ (A) and corresponding $\mathrm{IC}_{50}$ values of the fractions $(\mathrm{B})$.

\subsection{Purification of T. flavidus Peptides}

The fraction containing peptides of molecular weight $<1 \mathrm{kDa}$ was subjected to semipreparative liquid chromatography on a SinoChrom ODS-BP column as a pre-separation process. Through semi-preparative high-performance liquid chromatography, fractions A1-A8 were successively eluted from the column based on their molecular dimensions (Figure 3A). The eight fractions were collected and lyophilized, and their ACE-inhibitory activities were measured. After dilution to a concentration of $1 \mathrm{mg} / \mathrm{mL}$, they displayed ACE-inhibitory activities ranging from 20 to $90 \%$ (Figure 3B). Fraction A7, which showed the highest ACE-inhibitory activity (90\%), was then separated via Sephadex G-15 gel filtration chromatography into three major fractions (Figure 3C), of which, A7-c displayed the highest ACE-inhibitory activity $\left(\mathrm{IC}_{50}=0.34 \mathrm{mg} / \mathrm{mL}\right.$ ) (Figure 3D). Fraction A7-c was further separated using RP-HPLC on an analytical $\mathrm{C}_{18}$ column, and three major peaks, named A7-c-1 to A7-c-3, were obtained (Figure 3E). As shown in Figure 3F, fraction A7-c-2 showed the highest ACE-inhibitory activity $\left(\mathrm{IC}_{50}=0.24 \mathrm{mg} / \mathrm{mL}\right)$.

ACE-inhibitory peptides can be purified according to their MW, charge, affinity, and polarity [30-32]. Purification methods, such as size exclusion chromatography (Sephadex, Sepharose, Superdex, etc.), ion-exchange chromatography (DEAE-cellulose, DEAE-Sephadex, etc.), and RP-HPLC ( $\mathrm{C}_{18}, \mathrm{C}_{18}$, and other columns), are commonly used depending on the peptides' characteristics [33-36]. These protein purification procedures lead to appropriate separations. In our study, an ODS-BP column was employed for semi-preparative liquid chromatography as a pre-separation process, resulting in good separation efficiency for TFHs; Sephadex G-15 gel filtration chromatography was used to separate peptide fractions based on their MW. As the final step, RP-HPLC purified the peptides according to their hydrophobic character. The procedure of sequential chromatographic methods enabled us to effectively separate the active peptides of the TFHs. These results are consistent with those of other studies that isolated ACE-inhibitory peptides $[37,38]$. 


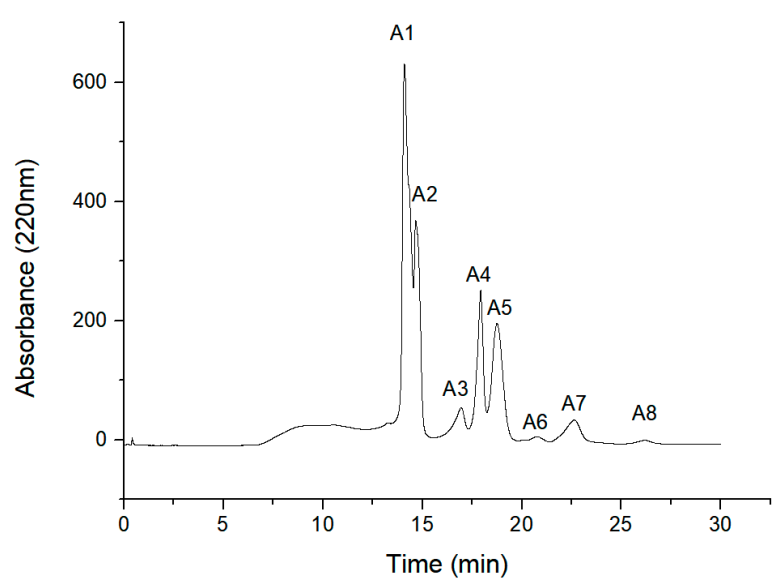

(A)

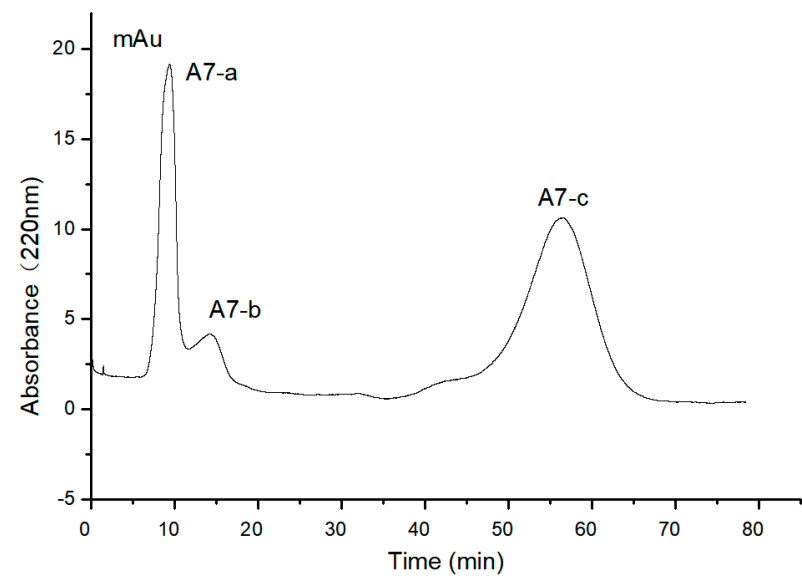

(C)

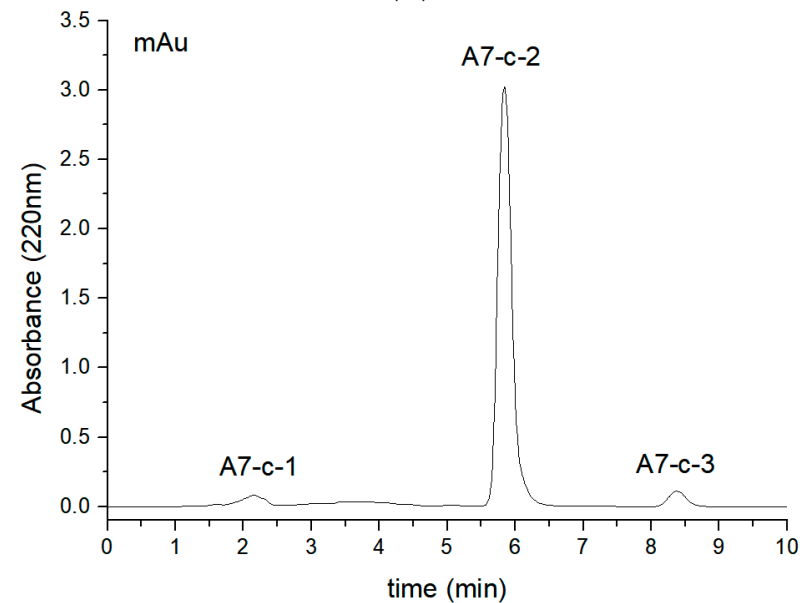

(E)

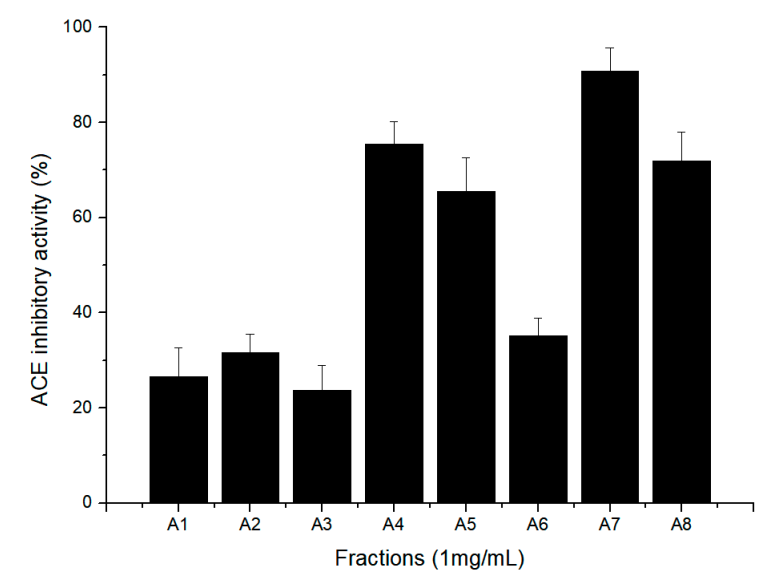

(B)

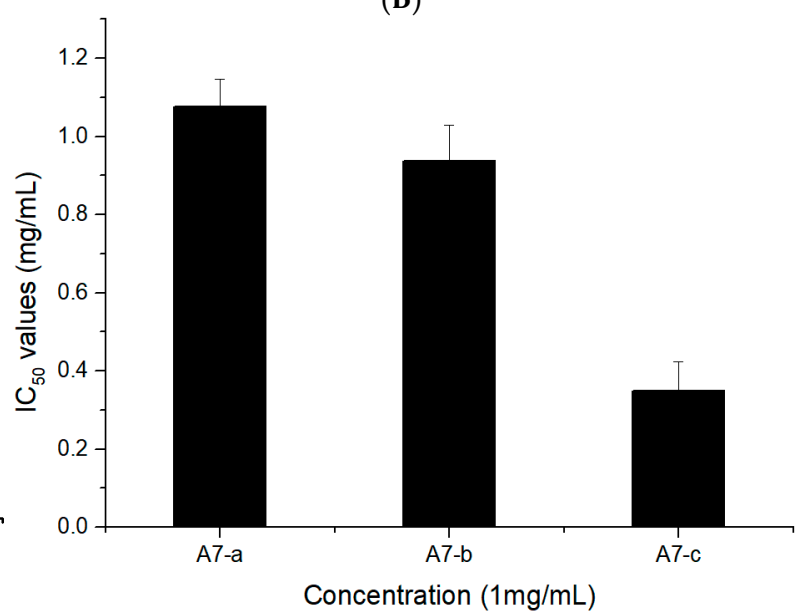

(D)

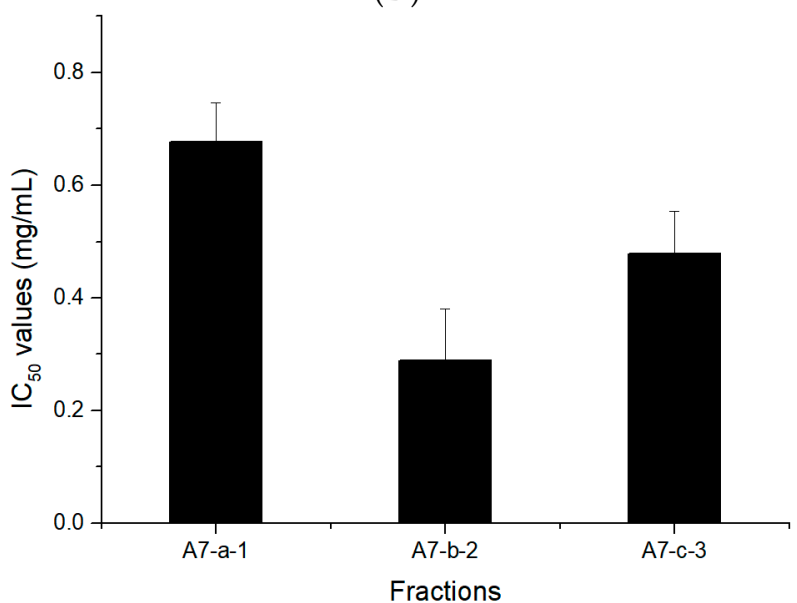

(F)

Figure 3. Purification of T. flavidus peptides: (A) chromatogram of the fractions that were isolated from the fraction of $<1 \mathrm{kDa}$ using semi-preparative liquid chromatography, (B) ACE-inhibitory activity of the fractions that were obtained via semi-preparative liquid chromatography, (C) chromatogram of the fractions that were isolated from A7 using Sephadex G-15 gel chromatography, (D) ACE-inhibitory activity of the fractions that were obtained via Sephadex G-15 gel chromatography, (E) chromatogram of the fractions that were isolated from A7-c using RP-HPLC, and (F) ACE-inhibitory activity of the fractions that were obtained via RP-HPLC. 


\subsection{Identification of T. flavidus Peptides and Peptide Synthesis}

To identify the potential ACE-inhibitory peptide, the most active sub-fraction, namely, A7-c-2, was analyzed using LC-MS/MS and identified with the PEAKS Studio software. As shown in Figure 4A, the amino acid sequence of the peptide was PPLLFAAL (ProPro-Leu-Leu-Phe-Ala-Ala-Leu, MW = 841.05 Da). The peptide had not been reported previously. It was chemically synthesized so that we could identify its ACE-inhibitory activity. The results showed that PPLLFAAL exhibited high ACE-inhibitory activity, with an $\mathrm{IC}_{50}$ value of $28 \mu \mathrm{mol} \cdot \mathrm{L}^{-1}$ (Figure $4 \mathrm{~B}$ ). The inhibition of PPLLFAAL was analyzed according to the Lineweaver-Burk plot method. The peptide was co-incubated with various substrate (hippuryl-L-histidyl-L-leucine (HHL)) concentrations and an ACE solution, and the corresponding double-reciprocal velocity-substrate plot is shown in Figure 4C. When the concentration of PPLLFAAL increased, $1 / \mathrm{V}_{\max }$ increased, whereas $\mathrm{V}_{\max }$ decreased and $\mathrm{K}_{\mathrm{m}}$ did not significantly change, which indicates that its inhibition mode may be a non-competitive one.

Previous studies revealed that amino acid sequence and hydrophobicity play important roles in the ACE-inhibitory activity of peptides. The presence of an aromatic amino acid (such as Pro, Tyr, or Phe) at the C-terminus and aromatic amino acids (such as Ile and Val) at the N-terminus significantly enhance the ACE inhibition $[39,40]$. Indeed, PPLLFAAL consisted of hydrophobic amino acids at the $\mathrm{N}$-terminus and aromatic amino acids at the C-terminus, and it also had a high content of hydrophobic amino acids. Hydrophobicity can support peptide-binding to a hydrophobic active center of ACE, thereby increasing the inhibitory activity [41]. In addition, hydrophobic peptides consisting of four to nine amino acids were shown to passively pass through cell membranes via transcytosis or para-cellular diffusion [33]. This suggested that PPLLFAAL might easily be absorbed, which allows it to cross the intestinal wall and enter the blood circulation.

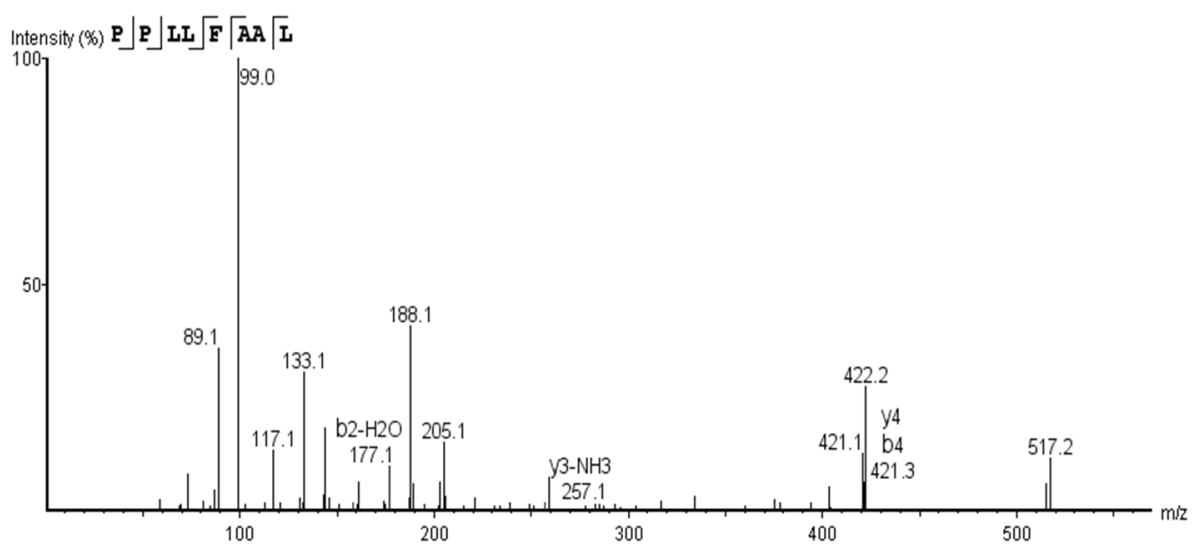

(A)

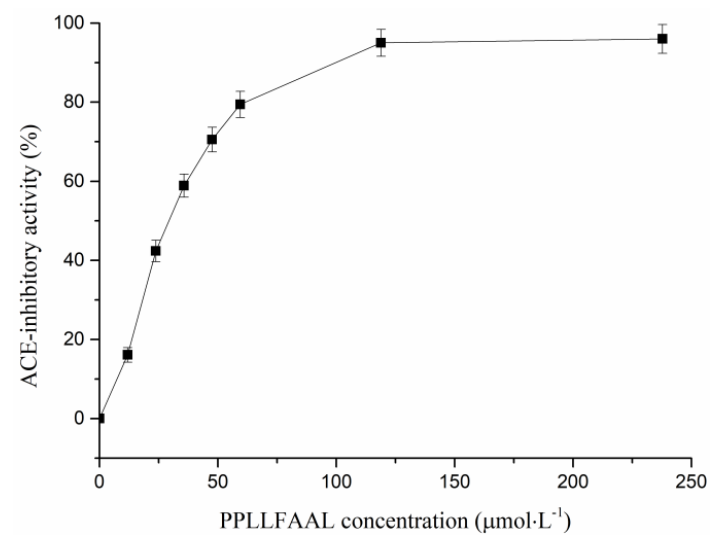

(B)

Figure 4. Cont. 


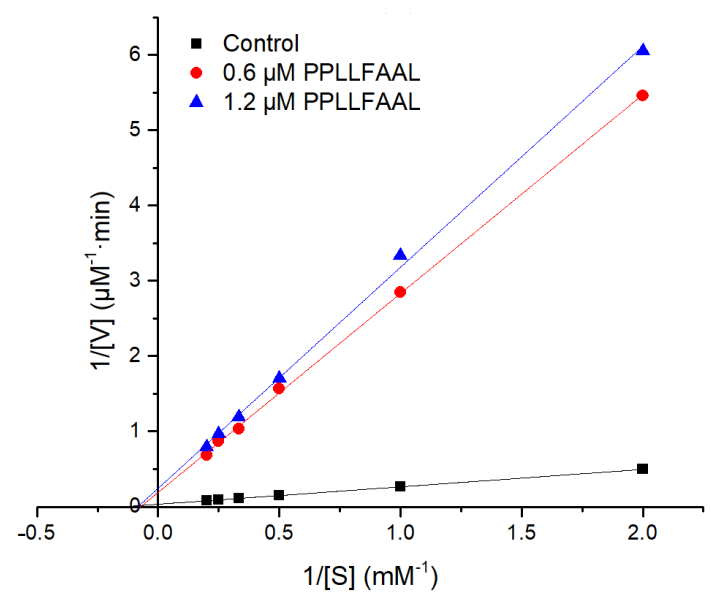

(C)

Figure 4. Identification of a T. flavidus peptide and its ACE-inhibitory activity: (A) MS/MS spectrum of the purified peptide using LC-MS/MS with an ESI source, (B) measurement of the ACE-inhibitory activity of PPLLFAAL at different concentrations, and (C) the Lineweaver-Burk plots of the reactions of ACE in the presence of PPLLFAAL. [S]: hippuryl-L-histidyl-L-leucine concentration; V: velocity of the reaction.

\subsection{Molecular Simulation of the Interaction between Peptides and ACE}

The ACE molecule contains three main active site pockets in the ACE catalytic site, named S1, S2, and S1' [34]. Hydrogen bond interactions play an irreplaceable role in stabilizing the structure of the enzyme-substrate complex; thus, they are essential for the ACE-catalyzed reaction [42]. Our molecular docking studies indicated that PPLLFAAL was bound to a narrow cavity inside ACE with a relatively extended conformation. The cavity had certain hydrophobicity and hydrophilicity, thanks to which, it could interact well with PPLLFAAL (Figure 5A). According to our simulations, the peptide was bound to the active site pocket of ACE through a network of hydrogen bonds and hydrophobic and van der Waals interactions (Figure 5B). In our model, PPLLFAAL formed 10 hydrogen bonds with residues Glu384, Ala354, Gln281, Lys511, Tyr520, His353, His383, His513, Gln369, and Ala356, and 12 hydrophobic interactions with residues Glu162, Phe457, Val380, Phe527, Glu376, Asp377, Leu161, Trp279, Phe512, Ser355, Val518, and Phe391. Namely, two hydrogen bonds were formed in the $\mathrm{S} 1$ active pocket (Ala354 and Glu384), five hydrogen bonds were formed with the S2 pocket (Gln281, His353, Lys511, His513, and Tyr520), and there were hydrophobic interactions with the $\mathrm{S1}^{\prime}$ pocket. The formation of these interactions greatly stabilized the enzyme-peptide complex. Furthermore, because ACE is a metalloenzyme with a zinc ion in the active site, which is coordinated with His348, Glu372, and His344, the presence of $\mathrm{Zn}$ (II) plays an important role in ACE inhibition [43]. The Leu3 of PPLLFAAL was coordinated to the $\mathrm{Zn}$ (II) ion, which may be the cause of the deactivation of ACE (Figure 5C). The stability of the ACE-peptide complex was studied using molecular dynamics (MD) simulations. Root-mean-square deviation (RMSD) is an important parameter that is used to indicate the stability of an enzyme-peptide system [44]. It reflects the extent to which protein molecules deviate from their initial structure with the peptide during the dynamic simulation. As shown in Figure 5D, the RMSD of the ACE-PPLLFAAL complex exhibited a large transition, from $0.11 \mathrm{~nm}$ to $0.15 \mathrm{~nm}$ in $3 \mathrm{~ns}$, then it floated around $0.16 \mathrm{~nm}$. The RMSD values below $0.2 \mathrm{~nm}$ during the MD simulations revealed that equilibration of the complex system had been achieved [45]. 


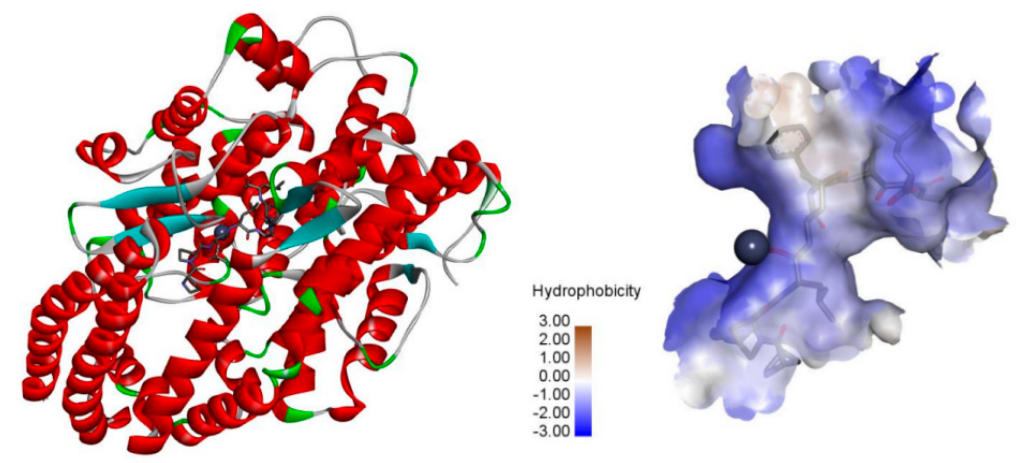

(A)

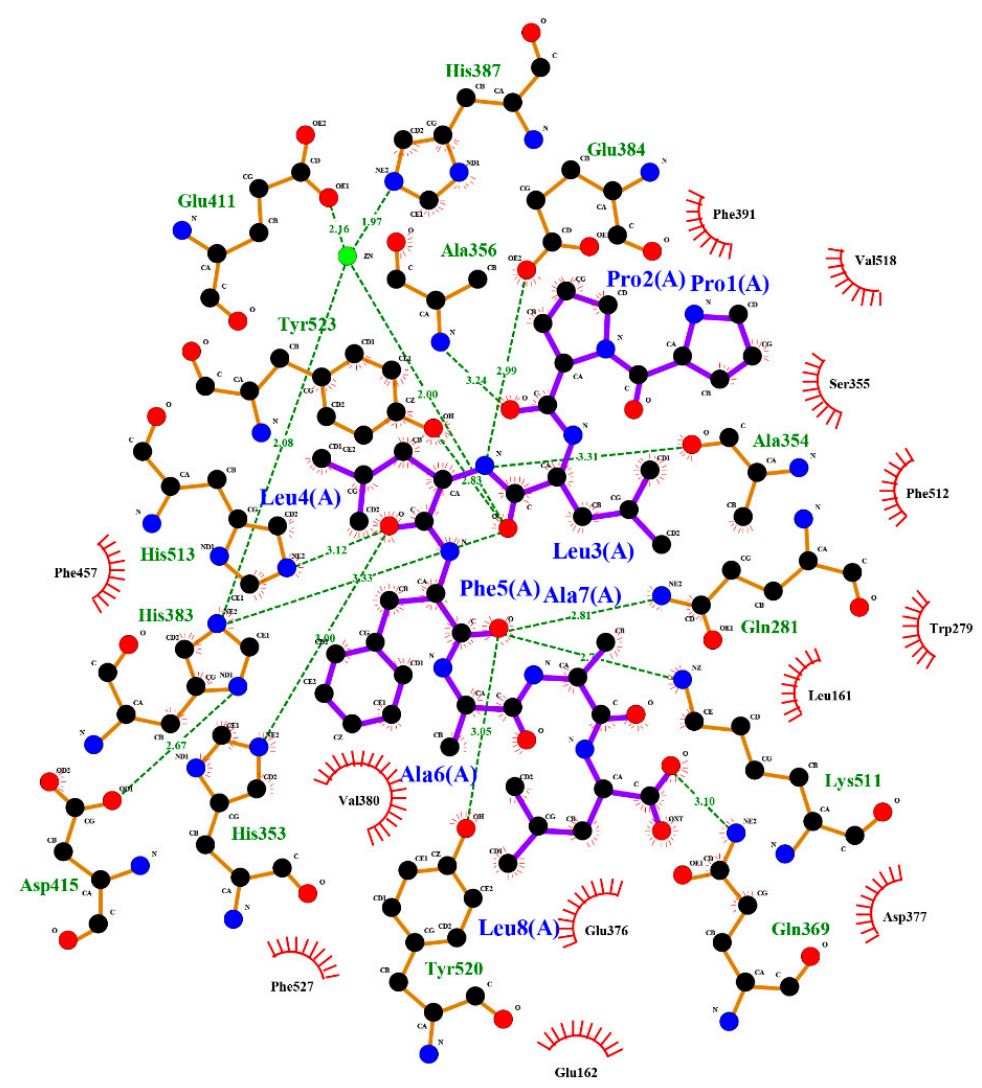

(B)

Figure 5. Cont. 


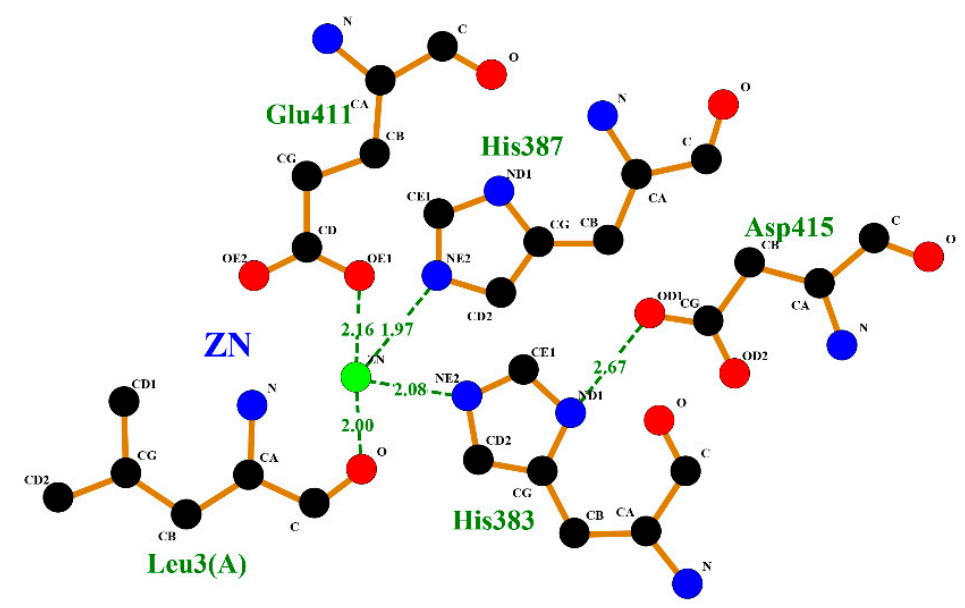

(C)

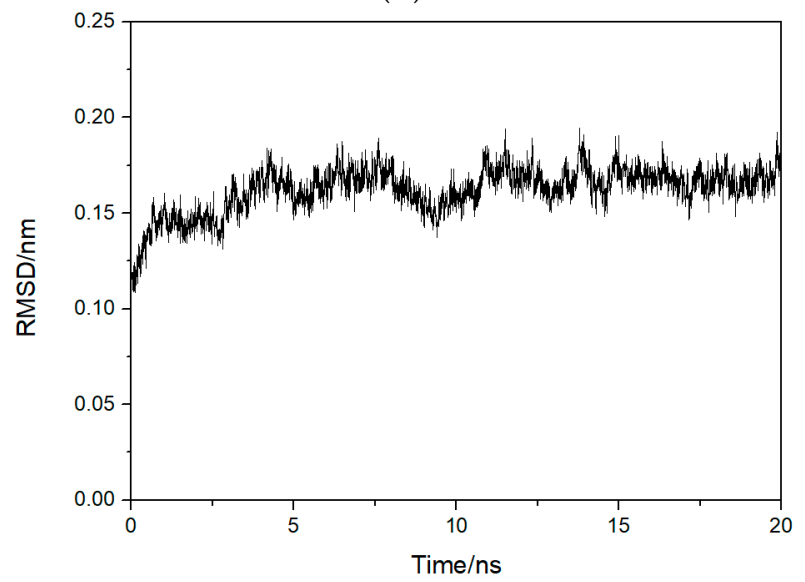

(D)

Figure 5. The molecular docking simulations of PPLLFAAL with ACE (PDB: 1O8A): (A) general overview and the best-ranked docking pose of peptide PPLLFAAL at the active site, $(\mathrm{B})$ the interactions between PPLLFAAL and the residues of ACE, $(\mathrm{C})$ the interactions between PPLLFAAL and the $\mathrm{Zn}^{2+}$ of ACE, and (D) the change in the root-mean-square deviation (RMSD) of the ACE-PPLLFAAL complex over time.

With the advent of molecular simulation techniques, molecular docking and MD simulations could be applied to study the structure-activity relationships between inhibitors and ACE at the molecular level. Tu et al. assessed the molecular docking of casein-derived peptides (NMAINP, NMAINPSK, and NMAINPSKE) against ACE using Discovery Studio 2017 R2 software and found that there were a total of five (Lys118, Asp121, Glu123, Glu403, Arg522), six (Lys118, Asp121, Glu123, Ala356, Glu411, Arg522), and ten (Asn66, Lys118, Asp121, Glu123, Arg124, Trp220, Tyr360, Ser516, Ser517, Arg522) kinds of ACE residues that formed H-bonds with NMAINP, NMAINPSK, NMAINPSKE, respectively [46]. Yu et al. evaluated the interaction mechanism of a peptide (NCW) and ACE using Discovery Studio 2019 software and confirmed that the higher inhibitory potency of NCW might be attributed to the formation of more hydrogen bonds with the ACE active site [47]. These findings are consistent with our results. Our simulation suggested that PPLLFAAL may inhibit ACE via interactions with amino acids at the active site and the zinc ion, thereby blocking the catalytic activity of ACE. PPLLFAAL could bind well to ACE and rapidly form a stable ACE-peptide complex. Hydrogen bonds and hydrophobic interactions between ACE and PPLLFAAL played an important role in maintaining the stability of the ACE complexes. 


\subsection{Antihypertensive Activity of the PPLLFAAL on SHRs}

The antihypertensive efficacy of PPLLFAAL in vivo was investigated in terms of changes in systolic blood pressure (SBP) and diastolic blood pressure (DBP) after intravenous administration to SHRs. As shown in Figure 6A, the SBP of the control group after the intravenous administration of saline did not change significantly during a $24 \mathrm{~h}$ period. Captopril- and PPLLFAAL-treated SHRs exhibited a significant decrease in SBP. Captopril significantly reduced the SBP (from 190 to $151 \mathrm{mmHg}$ at $4 \mathrm{~h}, p<0.05$ ), which then increased to $161 \mathrm{mmHg}$ at $24 \mathrm{~h}$. The SBP reduction curve that was obtained for PPLLFAAL was similar to that obtained with captopril. It was notable that the PPLLFAAL could maintain lower SBP levels for a longer period compared with the captopril group after intravenous administration. The results indicated that PPLLFAAL substantially reduced the SBP between 2 and $4 \mathrm{~h}(p<0.05)$, with the largest decrease in SBP from 193 to $145 \mathrm{mmHg}$ occurring at $4 \mathrm{~h}$. The SBP then began to recover and maintained a level of $154 \mathrm{mmHg}$ at $24 \mathrm{~h}$. In addition, PPLLFAAL could also affect the DBP (Figure 6B). PPLLFAAL could significantly reduce the DBP of SHRs from 135 to $107 \mathrm{mmHg}$ at $4 \mathrm{~h}(p<0.05)$, which was then restored to a level of $113 \mathrm{mmHg}$ at $24 \mathrm{~h}$.

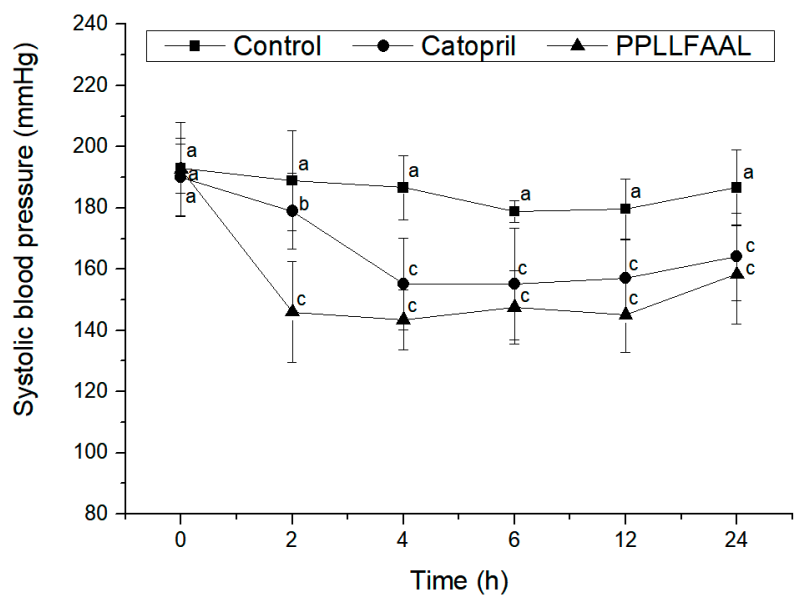

(A)

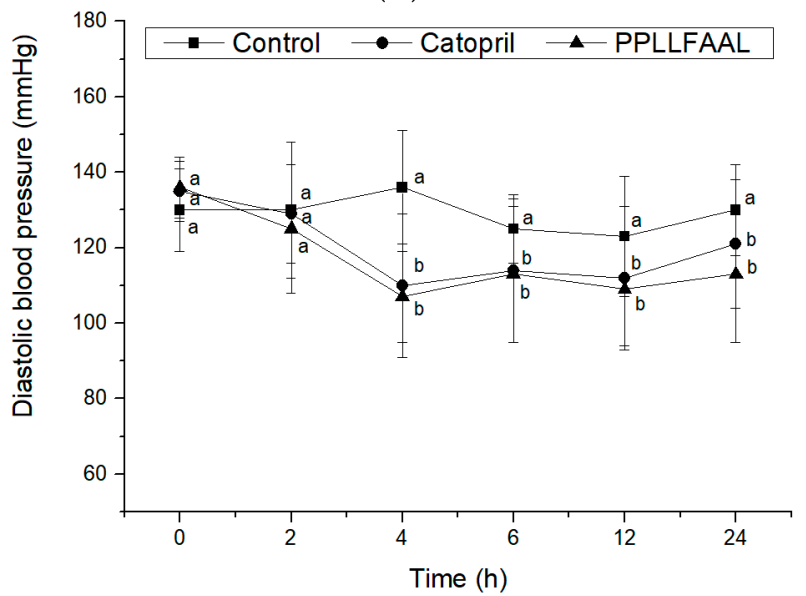

(B)

Figure 6. Changes in spontaneously hypertensive rats' blood pressure after the intravenous administration of PPLLFAAL: (A) SBP changes and (B) DBP changes. Different letters indicate statistically significant differences, as demonstrated using multiple one-way analysis of variance tests $(p<0.05)$.

ACE inhibition is often thought to play a key role in controlling blood pressure. Prior to this, ACE-inhibitory peptides are often characterized based on in vitro ACE inhibition. However, the relationship between in vitro ACE inhibition and antihypertensive activity is not apparent due to the complex biological factors, such as degradation by the digestive 
enzymes, the intestinal barrier, and plasma peptidases [48]. PPLLFAAL is a novel ACEinhibitory peptide that not only showed potent ACE-inhibitory activity in vitro but also showed effective and prolonged antihypertensive effects in SHRs. It indicated that the PPLLFAAL may maintain the high inhibitory activity in vivo and could effectively avoid the degradation in the blood. This result implied that PPLLFAAL could potentially be applied for the development of novel natural antihypertensive products.

\section{Materials and Methods}

\subsection{Materials and Chemicals}

T. flavidus were purchased from Fujian Shenhai Food (Zhangzhou, China) and the skins were peeled off and minced with a meat grinder. Alcalase (EC 3.4.21.62), neutral protease (EC 3.4.22.17), and pepsin (EC 3.4.23.1) were purchased from Solarbio (Beijing, China). ACE (EC 3.4.15.1, from rabbit lung), hippuryl-L-histidyl-L-leucine (HHL), acetonitrile (ACN, HPLC grade), captopril (>99\% purity), and trifluoroacetic acid (TFA) were purchased from Sigma Aldrich (St. Louis, MO, USA). Formic acid (FA) was supplied by Merck Chemical Company (Darmstadt, Germany). All other chemical reagents were of analytical grade.

\subsection{Preparation of TFHs}

Alcalase, pepsin, and trypsin were applied to investigate which would be the best enzymatic hydrolysis method, with the degree of hydrolysis and ACE-inhibitory activity as assessment indices. The skins of $T$. flavidus were hydrolyzed using different enzymes under the corresponding optimal temperature and $\mathrm{pH}$ conditions (alcalase, $\mathrm{pH} 8.0,55^{\circ} \mathrm{C}$; neutral protease, $\mathrm{pH} 7.0,55^{\circ} \mathrm{C}$; pepsin, $\mathrm{pH} 2.0,37^{\circ} \mathrm{C}$ ), with the same enzyme/substrate ratio of $2000 \mathrm{U} / \mathrm{g}$ and hydrolysis time of $5 \mathrm{~h}$. At the end of the hydrolysis, the hydrolysates were heated at $95{ }^{\circ} \mathrm{C}$ for $15 \mathrm{~min}$ to inactivate the enzymes. The TFHs were then centrifuged at $8000 \times g$ for $30 \mathrm{~min}$ at $4{ }^{\circ} \mathrm{C}$, and the supernatant was collected, freeze-dried, and stored at $-20{ }^{\circ} \mathrm{C}$ for further analysis. The degree of hydrolysis $(\mathrm{DH})$ was determined by measuring the nitrogen content that was soluble in $10 \%(v / v)$ trichloroacetic acid [17].

\subsection{Ultrafiltration of the ACE-Inhibitory Peptide}

The lyophilized TFH that was obtained with alcalase was dissolved in distilled water (50 g/L) and filtered sequentially using a continuous flow ultrafilter (STAR Biotechnology, Xiamen, China) with five ultrafiltration membranes with molecular weight (MW) cut-offs of 1, 3, 10, 30, and $50 \mathrm{kDa}$. Six fractions with MWs <1, 1-3, 3-10, 10-50, and >50 kDa were collected and lyophilized. Peptides with different molecular weights were accurately weighed and dissolved in distilled water to make different concentrations for assessing their ACE-inhibitory activity. The components with higher ACE activity were selected for further purification.

\subsection{Purification of the ACE-Inhibitory Peptide}

The $<1 \mathrm{kDa}$ fraction of TFHs was pre-separated using semi-preparative RP-HPLC with a SinoChrom ODS-BP semi-preparation column $(50 \mathrm{~mm} \times 400 \mathrm{~mm}$, Elite Technologies, Dalian, China). The sample was filtered through a $0.22 \mu \mathrm{m}$ filter and elutions were performed with a linear gradient of acetonitrile (10-40\%) at a flow rate of $1 \mathrm{~mL} \cdot \mathrm{min}^{-1}$ and absorbance wavelengths of $220 \mathrm{~nm}$.

The fraction with the highest ACE-inhibitory activity was then further purified using gel filtration chromatography according to the method described by Ma et al., with slight modifications [37]. The sample was loaded onto a Sephadex G-15 $(0.5 \mathrm{~cm} \times 100 \mathrm{~cm})$ and eluted using distilled water at a flow rate of $5 \mathrm{~mL} \cdot \mathrm{min}^{-1}$. The sample was separated and monitored at a wavelength of $220 \mathrm{~nm}$ using an AKTA pure 25 (GE Healthcare Bio-Sciences, Uppsala, Sweden).

Following gel filtration chromatography, the most active fraction was subjected to further isolation using RP-HPLC coupled with a $C_{18}$ analysis column $(\Phi 4.6 \times 250 \mathrm{~mm}$, Waters, Milford, CT, USA). The column was eluted with a linear gradient of solvent $B$ 
(acetonitrile containing $0.1 \%$ TFA) in solvent A (distilled water), changing from 5 to $25 \%$ in $25 \mathrm{~min}$ at a flow rate of $1 \mathrm{~mL} / \mathrm{min}$, and monitored at $220 \mathrm{~nm}$ [49]. The separation was repeated multiple times to obtain sufficient samples for the ACE-inhibitory activity assay. The fractions with the highest ACE-inhibitory activity were subjected to liquid chromatography-mass spectrometry (LC-MS/MS) analysis.

\subsection{Determination of ACE-Inhibitory Activity}

The ACE inhibition was measured using a modified spectrophotometric technique according to the method of Jianpeng Li et al. [50]. ACE and the substrate hippuryl-Lhistidyl-L-leucine (HHL, $5 \mathrm{mM}$ ) were dissolved in $0.1 \mathrm{M} \mathrm{Na}_{2}\left[\mathrm{~B}_{4} \mathrm{O}_{5}(\mathrm{OH})_{4}\right](\mathrm{pH}$ 8.3) with $0.3 \mathrm{M}$ sodium chloride. Then, $50 \mu \mathrm{L}$ of the sample solution and $150 \mu \mathrm{L}$ of the substrate HHL were added to a centrifuge tube, mixed, and incubated at $37^{\circ} \mathrm{C}$ for $5 \mathrm{~min}$. The ACE solution $\left(50 \mathrm{mU} / \mathrm{mL}\right.$ ) was added to start the reaction, and the sample was then incubated at $37^{\circ} \mathrm{C}$ for $45 \mathrm{~min}$. The reaction was terminated by adding $250 \mu \mathrm{L}$ of $1 \mathrm{M} \mathrm{HCl}$. The absorbance of the mixture was measured at $220 \mathrm{~nm}$ using an RP-HPLC system (Waters, Milford, MA, USA) on a SunFire $C_{18}$ column $(4.6 \times 250 \mathrm{~mm})$. The mobile phase comprised distilled water/acetonitrile (75:25 v/v, with $0.5 \%$ TFA) with a flow rate of $1 \mathrm{~mL} / \mathrm{min}$. External standard hippuric acid (HA) was used to calculate the concentration of HA. Distilled water was used as a control and the ACE-inhibitory activity (\%) was calculated according to Equation (1):

$$
\mathrm{ACE}-\text { inhibitory activity }(\%)=\frac{\mathrm{Ts}-\mathrm{T} 0}{\mathrm{Ts}} \times 100
$$

where $T_{S}$ is the peak area of hippuric acid with distilled water and $T_{0}$ is the peak area with the sample.

The $\mathrm{IC}_{50}$ value was defined as the peptide concentration of a sample that inhibited $50 \%$ of the ACE activity under the assay conditions.

\subsection{LC-MS/MS Analysis and Identification of Purified Peptide Sequences}

The separated peptides, obtained via the RP-HPLC, with the highest ACE-inhibitory activity were analyzed with a Q Exactive mass spectrometer (Thermo Fisher, Waltham, MA, USA). The parameters that were adopted for the instrument and methods were described by Tu et al. The sample was desalted and loaded onto a chromatographic column $(75 \mu \mathrm{M}$ i.d. $\times 150 \mathrm{~mm}$, packed with Acclaim PepMap RPLC $\mathrm{C}_{18}, 3 \mu \mathrm{m}, 100 \AA$ A). Then, $2 \%$ ACN $(0.1 \%$ formic acid, $v / v)$ and $80 \% \mathrm{ACN}$ (with $0.1 \%$ formic acid, $v / v$ ) were used as mobile phases A and B, respectively. Elutions were performed with a gradient of $6-95 \%$ B at a flow rate of $300 \mathrm{~nL} \cdot \mathrm{min}^{-1}$. The raw mass spectrometry test file was searched using PEAKS Studio software(PEAKS Studio Xpro, Bioinformatics Solutions Inc.) for the corresponding database.

\subsection{Chemical Synthesis of Peptides}

The screened and predicted potential ACEI peptide was chemically synthesized at Sangon Biotech Limited Corporation (Shanghai, China) using a solid phase method. The purity of the peptide was $98 \%$, which was verified by HPLC, and the sequence of the synthesized peptide was determined using HPLC-MS/MS. Synthetic PPLLFAAL was used for the validations of the ACE-inhibitory activity in vitro and in vivo and the determination of the $\mathrm{IC}_{50}$ values.

\subsection{Kinetics of ACE Inhibition}

The kinetic inhibition models of the T. flavidus peptides were tested using the method of Lin et al. [51]. Briefly, the ACE enzyme activities were measured with different concentrations of the substrate HHL $(0.5,1,2$, and $5 \mathrm{mM})$. The inhibitory pattern was determined using the Lineweaver-Burk plot of the reciprocal of the production speed of HA ( $y$-axis) versus the reciprocal of the substrate concentration ( $x$-axis). The $\mathrm{V}_{\max }$ and $\mathrm{K}_{\mathrm{m}}$ were calculated, respectively, as shown in the $y$ - and $x$-axis intercepts of the primary plot. 


\subsection{Molecular Simulations}

Molecular docking was performed to predict the conformation between ACE and PPLLFAAL using Discovery Studio 2019 software (NeoTrident Technology, Beijing, China). The crystal structure of ACE (PDB ID: 1O8A) was downloaded from the Protein Data Bank (PDB, https:/ / www.rcsb.org/structure/1O8A, 20 October 2021). Water molecules were removed and the zinc ion was retained in the ACE model [52]. The structure of PPLLFAAL was generated with Discovery Studio 2019 and the minimized energy was calculated with the CHARMM force field before molecular docking. The types of interactions between ACE and PPLLFAAL were analyzed. The best molecular docking result was selected based on its docking scores and the binding energy value [46].

The initial coordinates of the ACE-PPLLFAAL complexes for molecular dynamics (MD) simulations were chosen using the criterion of the lowest energy of the complex combined with visual inspection [53]. The MD simulations were performed using Amber software(Amber 20, University of California, San Francisco, CA, US) on the Yinfo Cloud Computing Platform (http://www.yinfotek.com/platform, 20 October 2021) with the parameters set according to Jiang et al. [54]. A subsequent MD simulation of $20 \mathrm{~ns}$ length was performed to study the equilibrium properties of the ACE-PPLLFAAL complexes.

\subsection{Antihypertensive Effect In Vivo}

Animals were obtained from Vital River Laboratory Animal Technology (Beijing, China), who also performed the blood pressure measurements in spontaneously hypertensive rats (SHRs) with a tail systolic blood pressure (SBP) of over $180 \mathrm{mmHg}$. Animals were fed a normal diet, and tap water was freely available. SHRs (11 weeks, $240 \pm 20 \mathrm{~g}$ body weight) were raised at room temperature $\left(25^{\circ} \mathrm{C}\right)$ under a $12 \mathrm{~h} \mathrm{light/dark}$ cycle. The antihypertensive effect of PPLLFAAL was evaluated by measuring changes in the SBP and DBP after intravenous injection with a single dose of $5 \mathrm{mg} / \mathrm{kg}$ body weight. Captopril $(5 \mathrm{mg} / \mathrm{kg}$ ) was used as a positive control, and the negative control group was injected with an equal volume of saline. The SBP and DBP of the rats were measured using the tail-cuff method before administration and at 2, 4, 6, 12, and $24 \mathrm{~h}$ post-administration, using a BP98A blood pressure monitor (Softron Biotechnology, Beijing, China) after heating the SHRs at $37^{\circ} \mathrm{C}$ for $30 \mathrm{~min}$ in a warming chamber. All the rats received humane care conforming to the National Institutes of Health Guide for Care and Use of Laboratory Animals. This study was approved by the Ethics Committee of Guangdong medical laboratory animal center (No. 20211001).

\subsection{Statistical Analysis}

Statistical analysis was performed using SPSS 19.0 software (SPSS Institute, Cary, NC, USA). Experimental data are presented as means \pm standard deviations (SD) and were statistically evaluated using one-way analysis of variance (ANOVA) with Duncan's test. Origin 9.0 (OriginLab, Northampton, MA, USA) software was used to process the data.

\section{Conclusions}

In this study, the skins of T. flavidus were used to prepare potential ACE-inhibitory peptides. The TFHs that were prepared using different proteases displayed diverse ACEinhibitory activities in vitro. The highest ACE-inhibitory activities were observed in the TFH that were prepared with alcalase. The components that were obtained using its ultrafiltration showed that the low-MW peptides $(<1 \mathrm{kDa})$ conferred the strongest ACEinhibitory activity. One novel potential ACE-inhibitory peptide (PPLLFAAL) was isolated from the peptide fraction with MW $<1 \mathrm{kDa}$ using semi-preparative HPLC, a Sephadex G-15, and RP-HPLC and identified using LC-MS/MS. PPLLFAAL showed high ACEinhibitory activity with an $\mathrm{IC}_{50}$ value of $28 \mu \mathrm{mol} \cdot \mathrm{L}^{-1}$ and appeared to be a non-competitive inhibitor. The molecular docking and molecular dynamics simulation results indicated that the peptides could firmly bind to ACE at the active site, as well as to zinc ions. Our results indicated that PPLLFAAL exhibited effective ACE-inhibitory activity in vitro, which makes 
it a potential candidate for the development of functional foods or anti-hypertensive drugs in the future.

Author Contributions: Writing—original draft, Y.S.; methodology, S.C. (Shicheng Chen) and J.S.; formal analysis, S.L. and N.P.; software, K.Q. and S.C. (Shuilin Cai); resources, B.C.; supervision, S.Y. and Z.L.; writing — review and editing, M.X. All authors have read and agreed to the published version of the manuscript.

Funding: This research was funded by the National Key Research and Development Program of China, grant number 2018YFD0901102, and the Special Funds of Fujian Ocean and Fisheries Structure Adjustment, grant number 2020HYJG06.

Institutional Review Board Statement: This study was conducted according to the guidelines of the Declaration of Helsinki and approved by the Ethics Committee of Guangdong medical laboratory animal center (No. 20211001).

Data Availability Statement: Not applicable.

Acknowledgments: We thank Zhiwei Yi, who provided us with the Discovery Studio 2019 software. We thank Guangzhou Yinfo Information Technology Co., Ltd. (Guangzhou, China), for providing a user-friendly and versatile webserver to aid with the MD simulation(s). Finally, I am grateful to my teacher Suping Yang for his guidance and support of my work.

Conflicts of Interest: The authors declare no conflict of interest.

\section{References}

1. Krivohlavý, J. Hypertension, cardiovascular diseases and defense mechanisms. Cas. Lek. Ceskych. 1989, 128, 617-620.

2. Daskaya-Dikmen, C.; Yucetepe, A.; Karbancioglu-Guler, F.; Daskaya, H.; Ozcelik, B. Angiotensin-I-converting enzyme (ACE)inhibitory peptides from plants. Nutrients 2017, 9, 316. [CrossRef]

3. Studdy, P.R.; Lapworth, R.; Bird, R. Angiotensin-converting enzyme and its clinical significance-A review. J. Clin. Pathol. 1983, 36, 938-947. [CrossRef] [PubMed]

4. Aluko, R.E. Antihypertensive peptides from food proteins. Annu. Rev. Food Sci. Technol. 2015, 6, 235-262. [CrossRef]

5. Abachi, S.; Bazinet, L.; Beaulieu, L. Antihypertensive and angiotensin-I-converting enzyme (ACE)-inhibitory peptides from fish as potential cardioprotective compounds. Mar. Drugs 2019, 17, 613. [CrossRef]

6. Bertrand, M. Provision of cardiovascular protection by ACE inhibitors: A review of recent trials. Curr. Med. Res. Opin. 2004, 20, 1559-1569. [CrossRef] [PubMed]

7. Wu, J.; Liao, W.; Udenigwe, C.C. Revisiting the mechanisms of ACE inhibitory peptides from food proteins. Trends Food Sci. Technol. 2017, 69, 214-219. [CrossRef]

8. FitzGerald, R.J.; Meisel, H. Milk protein-derived peptide inhibitors of angiotensin-I-converting enzyme. Br. J. Nutr. 2000, 84, S33-S37. [CrossRef]

9. Wijesekara, I.; Kim, S.K. Angiotensin-I-converting enzyme (ACE) inhibitors from marine resources: Prospects in the pharmaceutical industry. Mar. Drugs 2010, 8, 1080-1093. [CrossRef]

10. Mirdhayati, I.; Hermanianto, J.; Wijaya, C.H.; Sajuthi, D.; Arihara, K. Angiotensin converting enzyme (ACE) inhibitory and antihypertensive activities of protein hydrolysate from meat of Kacang goat (Capra aegagrus hircus). J. Sci. Food Agric. 2016, 96, 3536-3542. [CrossRef] [PubMed]

11. Rudolph, S.; Lunow, D.; Kaiser, S.; Henle, T. Identification and quantification of ACE-inhibiting peptides in enzymatic hydrolysates of plant proteins. Food Chem. 2017, 224, 19-25. [CrossRef]

12. Vercruysse, L.; Camp, J.; Smagghe, G. ACE Inhibitory peptides derived from enzymatic hydrolysates of animal muscle protein: A review. J. Agric. Food Chem. 2005, 53, 8106-8115. [CrossRef] [PubMed]

13. Martínez-Maqueda, D.; Miralles, B.; Recio, I.; Hernández-Ledesma, B. Antihypertensive peptides from food proteins: A review. Food Funct. 2012, 3, 350-361. [CrossRef] [PubMed]

14. Ghassem, M.; Arihara, K.; Babji, A.S.; Said, M.; Ibrahim, S. Purification and identification of ACE inhibitory peptides from Haruan (Channa striatus) myofibrillar protein hydrolysate using HPLC-ESI-TOF MS/MS. Food Chem. 2011, 129, 1770-1777. [CrossRef]

15. Liu, X.; Zhang, M.; Shi, Y.; Qiao, R.; Tang, W.; Sun, Z. Production of the angiotensin I converting enzyme inhibitory peptides and isolation of four novel peptides from jellyfish (Rhopilema esculentum) protein hydrolysate. J. Sci. Food Agric. 2016, 96, 3240-3248. [CrossRef]

16. Wu, H.; He, H.L.; Chen, X.L.; Sun, C.Y.; Zhang, Y.Z.; Zhou, B.C. Purification and identification of novel angiotensin-I-converting enzyme inhibitory peptides from shark meat hydrolysate. Process Biochem. 2008, 43, 457-461. [CrossRef]

17. Lee, S.-H.; Qian, Z.-J.; Kim, S.-K. A novel angiotensin I converting enzyme inhibitory peptide from tuna frame protein hydrolysate and its antihypertensive effect in spontaneously hypertensive rats. Food Chem. 2010, 118, 96-102. [CrossRef] 
18. Zhang, G.; Shi, Y.; Zhu, Y.; Liu, J.; Zang, W. Effects of salinity on embryos and larvae of tawny puffer Takifugu flavidus. Aquaculture 2010, 302, 71-75. [CrossRef]

19. Gao, Y.; Gao, Q.; Zhang, H.; Zhang, F.; Yang, C.; Song, L. Draft sequencing and analysis of the genome of pufferfish Takifugu flavidus. DNA Res. 2014, 21, 627-637. [CrossRef]

20. Chen, J.; Li, M.; Yi, R.; Bai, K.; Wang, G.; Tan, R.; Sun, S.; Xu, N. Electrodialysis extraction of Pufferfish skin (Takifugu flavidus): A promising source of collagen. Mar. Drugs 2019, 17, 25. [CrossRef] [PubMed]

21. Sun, S.; Xu, X.; Sun, X.; Zhang, X.; Chen, X.; Xu, N. Preparation and identification of ACE inhibitory peptides from the marine macroalga Ulva intestinalis. Mar. Drugs 2019, 17, 179. [CrossRef] [PubMed]

22. Nekliudov, A.D.; Ivankin, A.; Bertudina, A.V. Characteristics and use of protein hydrolysates (review). Prikl. Biokhimiia Mikrobiol. 2000, 36, 525-534.

23. Nasri, M. Protein hydrolysates and biopeptides: Production, biological activities, and applications in foods and health benefits. A review. Adv. Food Nutr. Res. 2017, 81, 109-159. [CrossRef] [PubMed]

24. Wisuthiphaet, N.; Kongruang, S.; Chamcheun, C. Production of fish protein hydrolysates by acid and enzymatic hydrolysis. J. Med. Bioeng. 2015, 4, 466-470. [CrossRef]

25. Zheng, Y.; Wang, X.; Zhuang, Y.; Li, Y.; Shi, P.; Tian, H.; Li, X.; Chen, X. Isolation of novel ACE-inhibitory peptide from naked oat globulin hydrolysates in silico approach: Molecular docking, in vivo antihypertension and effects on renin and intracellular endothelin-1. J. Food Sci. 2020, 85, 1328-1337. [CrossRef]

26. Kheeree, N.; Sangtanoo, P.; Srimongkol, P.; Saisavoey, T.; Reamtong, O.; Choowongkomon, K.; Karnchanatat, A. ACE inhibitory peptides derived from de-fatted lemon basil seeds: Optimization, purification, identification, structure-activity relationship and molecular docking analysis. Food Funct. 2020, 11, 8161-8178. [CrossRef]

27. Abdelhedi, O.; Nasri, R.; Jridi, M.; Mora, L.; Oseguera-Toledo, M.; Aristoy, M.-C.; Ben Amara, I.; Toldrá, F. In silico analysis and antihypertensive effect of ACE-inhibitory peptides from smooth-hound viscera protein hydrolysate: Enzyme-peptide interaction study using molecular docking simulation. Process Biochem. 2017, 58, 145-159. [CrossRef]

28. Ryan, J.T.; Ross, R.P.; Bolton, D.; Fitzgerald, G.F.; Stanton, C. Bioactive peptides from muscle sources: Meat and fish. Nutrients 2011, 3, 765-791. [CrossRef] [PubMed]

29. Sirtori, C.R.; Galli, C.; Anderson, J.W.; Arnoldi, A. Nutritional and nutraceutical approaches to dyslipidemia and atherosclerosis prevention: Focus on dietary proteins. Atherosclerosis 2009, 203, 8-17. [CrossRef]

30. Sun, M.-L.; Zhang, Q.; Ma, Q.; Fu, Y.-H.; Jin, W.-G.; Zhu, B.-W. Affinity purification of angiotensin-converting enzyme inhibitory peptides from Volutharpa ampullacea perryi protein hydrolysate using Zn-SBA-15 immobilized ACE. Eur. Food Res. Technol. 2017, 244, 457-468. [CrossRef]

31. Tian, L.; Liu, J.; Ma, L.; Zhang, L.; Wang, S.; Yan, E.; Zhu, H. Isolation and purification of antioxidant and ACE-inhibitory peptides from Yak (Bos grunniens) skin. J. Food Process. Preserv. 2017, 41, e13123. [CrossRef]

32. Mane, S.; Jamdar, S.N. Purification and identification of Ace-inhibitory peptides from poultry viscera protein hydrolysate. J. Food Biochem. 2017, 41, e12275. [CrossRef]

33. Abdelhedi, O. Basic and recent advances in marine antihypertensive peptides: Production, structure-activity relationship and bioavailability. Trends Food Sci. Technol. 2019, 88, 543-557. [CrossRef]

34. Pan, D.; Cao, J.; Guo, H.; Zhao, B. Studies on purification and the molecular mechanism of a novel ACE inhibitory peptide from whey protein hydrolysate. Food Chem. 2012, 130, 121-126. [CrossRef]

35. Jakubczyk, A.; Baraniak, B. Angiotensin I converting enzyme inhibitory peptides obtained after in vitro hydrolysis of pea (Pisum sativum var. Bajka) globulins. BioMed Res. Int. 2014, 2014, 438459. [CrossRef]

36. Montone, C.M.; Capriotti, A.L.; Cavaliere, C.; La Barbera, G.; Piovesana, S.; Zenezini Chiozzi, R.; Lagana, A. Peptidomic strategy for purification and identification of potential ACE-inhibitory and antioxidant peptides in Tetradesmus obliquus microalgae. Anal. Bioanal. Chem. 2018, 410, 3573-3586. [CrossRef]

37. Chen, Y.; Gao, X.; Wei, Y.; Liu, Q.; Jiang, Y.; Zhao, L.; Ulaah, S. Isolation, purification and the anti-hypertensive effect of a novel angiotensin I-converting enzyme (ACE) inhibitory peptide from Ruditapes philippinarum fermented with Bacillus natto. Food Funct. 2018, 9, 5230-5237. [CrossRef] [PubMed]

38. Liao, P.; Lan, X.; Liao, D.; Sun, L.; Zhou, L.; Sun, J.; Tong, Z. Isolation and characterization of angiotensin I-converting enzyme (ACE) inhibitory peptides from the enzymatic hydrolysate of carapax trionycis (the shell of the Turtle Pelodiscus sinensis). $J$. Agric. Food Chem. 2018, 66, 7015-7022. [CrossRef]

39. Shi, J.; Su, R.Q.; Zhang, W.T.; Chen, J. Purification and the secondary structure of a novel angiotensin I-converting enzyme (ACE) inhibitory peptide from the alcalase hydrolysate of seahorse protein. J. Food Sci. Technol. 2020, 57, 3927-3934. [CrossRef] [PubMed]

40. Kapel, R.; Rahhou, E.; Lecouturier, D.; Guillochon, D.; Dhulster, P. Characterization of an antihypertensive peptide from an Alfalfa white protein hydrolysate produced by a continuous enzymatic membrane reactor. Process Biochem. 2006, 41, 1961-1966. [CrossRef]

41. Nuchprapha, A.; Paisansak, S.; Sangtanoo, P.; Srimongkol, P.; Saisavoey, T.; Reamtong, O.; Choowongkomon, K.; Karnchanatat, A. Two novel ACE inhibitory peptides isolated from longan seeds: Purification, inhibitory kinetics and mechanisms. RSC Adv. 2020, 10, 12711-12720. [CrossRef]

42. Fu, Y.; Alashi, A.; Young, J.; Therkildsen, M.; Aluko, R. Enzyme inhibition kinetics and molecular interactions of patatin peptides with angiotensin I-converting enzyme and renin. Int. J. Biol. Macromol. 2017, 101, 207-213. [CrossRef] [PubMed] 
43. Pina, A.; Roque, A. Studies on molecular recognition between bioactive peptides and angiotensin-converting enzyme. J. Mol. Recognit. 2009, 22, 162-168. [CrossRef] [PubMed]

44. Jalkute, C.B.; Barage, S.H.; Dhanavade, M.J.; Sonawane, K.D. Molecular dynamics simulation and molecular docking studies of Angiotensin converting enzyme with inhibitor lisinopril and amyloid beta peptide. Protein J. 2013, 32, 356-364. [CrossRef]

45. Qi, C.; Zhang, R.; Liu, F.; Zheng, T.; Wu, W. Molecular mechanism of interactions between inhibitory tripeptide GEF and angiotensin-converting enzyme in aqueous solutions by molecular dynamic simulations. J. Mol. Liq. 2018, 249, 389-396. [CrossRef]

46. Tu, M.; Wang, C.; Chen, C.; Zhang, R.; Liu, H.; Lu, W.; Jiang, L.; Du, M. Identification of a novel ACE-inhibitory peptide from casein and evaluation of the inhibitory mechanisms. Food Chem. 2018, 256, 98-104. [CrossRef]

47. Yu, Z.; Wu, S.; Zhao, W.; Ding, L.; Shiuan, D.; Chen, F.; Li, J.; Liu, J. Identification and the molecular mechanism of a novel myosin-derived ACE inhibitory peptide. Food Funct. 2018, 9, 364-370. [CrossRef]

48. Kompella, U.B.; Lee, V.H. Delivery systems for penetration enhancement of peptide and protein drugs: Design considerations. Adv. Drug Deliv. Rev. 2001, 46, 211-245. [CrossRef]

49. Zheng, Y.; Wang, X.; Zhuang, Y.; Li, Y.; Tian, H.; Shi, P.; Li, G. Isolation of novel ACE-inhibitory and antioxidant peptides from quinoa bran albumin assisted with an in silico approach: Characterization, in vivo Antihypertension, and Molecular docking. Molecules 2019, 24, 4562. [CrossRef]

50. Li, J.; Liu, Z.; Zhao, Y.; Zhu, X.; Yu, R.; Dong, S.; Wu, H. Novel natural angiotensin converting enzyme (ACE)-inhibitory peptides derived from sea cucumber-modified hydrolysates by adding exogenous proline and a study of their structure(-)activity relationship. Mar. Drugs 2018, 16, 271. [CrossRef]

51. Lin, K.; Zhang, L.-W.; Han, X.; Cheng, D.-Y. Novel angiotensin I-converting enzyme inhibitory peptides from protease hydrolysates of Qula casein: Quantitative structure-activity relationship modeling and molecular docking study. J. Funct. Foods 2017, 32, 266-277. [CrossRef]

52. Zhao, W.; Xue, S.; Yu, Z.; Ding, L.; Li, J.; Liu, J. Novel ACE inhibitors derived from soybean proteins using in silico and in vitro studies. J. Food Biochem. 2019, 43, e12975. [CrossRef]

53. Wu, X.; Li, Q.; Wan, S.; Zhang, J. Molecular dynamics simulation and free energy calculation studies of the binding mechanism of allosteric inhibitors with TrkA kinase. J. Biomol. Struct. Dyn. 2021, 39, 202-208. [CrossRef] [PubMed]

54. Jiang, Z.; Zhang, H.; Bian, X.; Li, J.; Li, J.; Zhang, H. Insight into the binding of ACE-inhibitory peptides to angiotensin-converting enzyme: A molecular simulation. Mol. Simul. 2018, 45, 1-8. [CrossRef] 